\title{
PRECARIOUS WORK AND HUMAN TRAFFICKING - GLOBAL CHALLENGES, GLOBAL SOLUTIONS
}

\author{
Radoslav Stamenkov ${ }^{1}$
}

DOI: https://doi.org/10.31410/ERAZ.2019.101

\begin{abstract}
The paper focuses on a problem identified as one of the scourges of modern society - human trafficking. The text contributes to the literature on the topic by analysing the link between precarious work, unemployment and their interrelationship with migration, and the growing vulnerability of large groups of people to fall into trafficking. Through a secondary analysis of documents and a statistics analysis, gathered by international institutions, a context is presented in which the vulnerability of people to human trafficking is increased and defends the assertion that a solution to the problem should be sought at the macro level - by adopting international agreements on joint activities and efforts against this phenomenon, as well as on the meso and micro level.
\end{abstract}

Keywords: poverty, human trafficking, precarious work.

\section{INTRODUCTION}

Tn the modern world many opportunities for work, travel and other various forms of realization arise. We live in a world of unprecedented human mobility. Migration today is more than ever a global issue - a priority for all governments.

The world's workforce has, also, never been more mobile. Every person travelling from country to country is trying to secure a better life for themselves and their family. It is exactly the economic motives which drive migration, together with the willingness to travel and the availability of informal connections and networks [1]. Everyone - skilled or unskilled, with work permits or without - is seeking an identical goal: more opportunities for realization and a better life for themselves and their family. Migration is practically the oldest strategy to combat poverty.

The lower security, created by all these factors, is largely exploited by human-traffickers. Trafficking in human beings has, predominantly, been seen as a crime which affects mostly women, but over time it has been acknowledged that men and boys are also vulnerable to this crime, especially trafficking for labour exploitation. But what are the circumstances that favour human trafficking and labour exploitation?

\section{FACTORS FAVORING HUMAN TRAFFICKING}

According to researchers [2], human trafficking was formed as a social problem in the end of the nineteenth century in Europe and North America when industrialization, urbanization and unequal distribution of wealth lead to an increased migration. The phenomena gain momentum in the twentieth century and is constantly rising to reach its peak in today's world in the face of globalization and free movement of people. 
This natural mobility and labour migration can result in enormous communal benefits for individuals and countries, of both origin and destination, when done in a safe and orderly way. Unfortunately, statistics remind us that migrants are exposed to disproportionate risks of exploitation and abuse in seeking better job opportunities away from home. Every year, millions of migrants are trafficked within and outside of their country's borders and find themselves trapped in forced labour or victims of sexual exploitation.

The prosperity of human trafficking is caused by many things, but firstly it is affected by poverty and material deprivation, followed by factors such as lack of employment in the home country and lack of social or economic opportunities for development; dangers from military conflicts and political instability, and human rights violations [3, p. 424].

In regards to studies and researches on the topic worldwide, this is the picture in numbers:

- In 2017, nearly 736 million of the world's population still lives in extreme poverty, with less than $\$ 1.9$ a day [4];

- According to the International Labour Organization, 40 million people are victims of modern slavery in 2016, with nearly 25 million of them suffering from forced labour [5];

- More than 700 million women are married before they reach the age of 18 , and one in three - before the age of 15 [6];

- In the period 2015-2016 over half (56\%) of trafficked persons were victims of sexual exploitation. About a quarter or $26 \%$ were trafficked for labour exploitation, while the remaining percentage consisted of forced begging and organ trafficking [7];

In many cases, both men and women are forced to work in an environment of violence, threats and psychological manipulation. Employees often find themselves indebted through non-transparent recruitment practices and detrimental working conditions, while at the same time being subjected to tremendous pressure from their families who expect from them to send money, so they can survive in their country of origin.

Other forms of exploitation remain more hidden, but not less harmful - life-threatening working conditions, symbolic pay or household services, vague clauses on income deductions and additional taxation; unacceptable restrictions on personal freedom within the working time, and even beyond the working day. These and other similar characteristics, as well as new studies [8], demonstrate that these can be understood as precarious jobs which combines the ideas of insecure employment and low-quality work, and rather indicates the results of a series of forces operating for several decades. It is no longer sufficient to just talk about the availability of work, but also about its quality. In many places around the world, although people are employed, they cannot escape of the state of poverty they are in. Poverty and precarious work can be defined as the main determinants for vulnerability of falling into labour exploitation conditions and human trafficking. Situations of financial scarcity, when you have nothing to put on the table or what to clothe your child with to go to school, bring parents to a position to accept offers for work abroad.

The economic and technological developments, we are seeing today, according to researchers [9], give more chances for the advancement of highly qualified and well-educated people, and the risk of unemployment, exclusion from the labour market and social marginalization is increased for the low-skilled. Social and political changes not only lag behind, but also lead to a reduction in labour security. The latter has been displaced by the idea of economic rationality, 
leading primarily to global business efforts for reducing labour costs and increasing profits. The result, according to Standing [10], is the emergence of a dangerous new class - precariat - consisting of millions of people around the world living without any security, united by characteristics such as poor lifestyle, ill paid work, poor working conditions and social insecurity. According to Eurostat data only in the EU27, the percentage of the working poor in 2017 was $9.4 \%$, with an increase of this percentage steadily trending since 2010. Major social inequalities and regional disparities create significant difficulties, especially in poorer countries (such as Bulgaria). These regional disparities prove to be a significant factor, prompting people, especially the younger, to look for work abroad [8].

And in order to not only rely on figures and data, we can briefly present two specific cases of victims of trafficking who have received help from the IOM mission in Bulgaria:

- $\mathrm{R}$. is a village boy who wants to have a good life, to be able to afford an expensive phone and to take his girlfriend to a restaurant and a club in the nearby bigger city. So, he needs money, and the possibilities for work in his village are limited. At the bus stop in the centre, R. coincidentally sees an ad about blueberry pickers in Sweden. The promised payment seems great to him, and without much thought, R. calls the indicated phone number and not long after he is taken from the same station, driven to Sofia and from there with many more like him - to Sweden. It turns out that in Sweden he will not pick blueberries. R. and the rest in his group are forced to beg on the central boulevards and in front of large stores in Malmö.

- C. is 19 years old, from a small Bulgarian town. After finishing her secondary education, she is faced with the decision of what to do next. She wants to travel, but she needs work to support herself. Acquaintances promise her an opportunity for work in Greece, so she leaves Bulgaria. It turns out she will not work as a waitress in Athens, as previously agreed. They take her passport and all her documents, lock her up and force her to prostitute.

The forms of human trafficking, where people are cruelly exploited by other people are largely diverse and bring enormous profits to criminals [11]. The latter takes advantage of people's vulnerability and their desire for a better life, which means that the struggle with this criminal phenomenon depends not only on the capacity of law enforcement but also on a number of other conditions - economic, social, cultural. It would be difficult to achieve positive results in combating human trafficking, unless the potency of factors such as poverty, inequality, discrimination, political instability and military conflicts is reduced. Therefore, measures should be implemented on both the international and national level. The efforts of each citizen individually are of particular importance.

\section{JOINT EFFORTS IN COMBATING TRAFFICKING IN HUMAN BEINGS}

The international community and state leaders have recognized the significant scope of human trafficking and the numerous problems that need to be surmounted in order to achieve success in combating this crime. The inclusion (indirectly and directly) of Countering and Combating Human Trafficking in the Sustainable Development Goals 2030 is a proof of this action. The Sustainable Development Goals replace and build on the Millennium Development Goals, adopted at the United Nations Headquarters in September of 2015, and focus on people, prosperity, peace and partnership. A main priority of the Goals is to "balance the three dimensions of sustainable development: the economic, social and environmental." [12] They are trying to respond 
to the global challenges, faced by all people and related to poverty, inequality, climate change, social progress, justice and peace. The Goals are interrelated, and their main task is to "leave no one behind", i.e. everybody gets what they need to live a decent life with access to equal opportunities as everyone else, this being achieved with the help of the governments of states.

Three of the Sustainable Development Goals explicitly concern human trafficking - number 5, number 8 and number 16. Namely, "Achieve gender equality and empower all women and girls", "Promote sustained, inclusive and sustainable economic growth, full and productive employment and decent work for all" and "Promote peaceful and inclusive societies for sustainable development, provide access to justice for all and build effective, accountable and inclusive institutions at all levels."

Recognizing the lack of gender equality as a significant prerequisite for vulnerability to trafficking and exploitation of women, in sub-objective 5.2, the international community calls on States to "Eliminate all forms of violence against all women and girls in the public and private spheres, including trafficking and sexual and other types of exploitation." Many of the other sub-targets for Goal 5 are related to trafficking, including the elimination of harmful practices such as early marriages and the call for valuation of unpaid care and housekeeping. Even though the balance between work and family life has been widely discussed in scientific literature over the last two to three decades, especially in view of the opportunities that technology offers for telework [13] in many societies there are still large gender gaps in the responsibility for childcare and adult care, pay and job choices and not in women's benefit [14], [15]. During the 21st century, in many societies and ethnic groups, women still do not have the same rights as men.

Efforts in terms of gender equality would not be effective if there were no conditions for development in the individual countries - economic and social. People's development firstly involves access to quality education and quality work, enabling a decent life. Objective number 8 and its sub-targets focus mainly on the access to decent and stable work. This requires investment by the state in creating sustainable jobs, a secure environment for living and working by reducing corruption levels, creating good conditions for foreign investment and higher economic growth. In this way, one of the main reasons for trafficking, namely poverty and precarious work is addressed.

Goal 16 addresses the efforts to "Promote peaceful and inclusive societies for sustainable development, provide access to justice for all and build effective, accountable and inclusive institutions at all levels." Sub-objective 16.2 calls on nations to "End abuse, exploitation, trafficking and all forms of violence against and torture of children." Other sub-objectives, such as the battle against organized crime, the rule of law and the reduction of all forms of violence, are also related to the elimination of trafficking in human beings.

In addition to the adoption of the Sustainable Development Goals in September 2015, as well as the reform of the European legal framework, strategies and directives on human trafficking, another key event has taken place, which fully deals with migration as a global phenomenon - the adoption of the Global Compact for Safe, Orderly and Regular Migration by the UN in December 2018. The development of the Global Compact on Migration is a historic opportunity for the international community to put an end to fragmented activities. The formal start of the process of drafting a Global Migration Pact was in September 2016, when the UN General Assembly adopted the New York Declaration on Refugees and Migrants [16]. Since this year, the EU has 
been actively and continuously involved in the process of drafting the Global Migration Pact through a coordinated approach. A successful policy is measured not only with the increase of people's well-being in their home country, but also with the protection and integration of anyone who wants to build their lives in another country.

In addition to a supranational level, efforts should also be made at the medium and micro levels. On one hand are educational institutions, non-governmental organizations, trade unions, employers and others. They are all of great importance for the quality of labour market relations in a given country, for discrimination against women or ethnic minorities [17], [18]. On the other hand, each of us can make efforts not to encourage the trafficking and exploitation of people. As consumers, while continuously looking for a better balance between the price and quality of goods and services, we could consider the workers who produce certain commodities or help a service to reach us - the conditions in which they work, and the pay which they receive for their labour.

\section{CONCLUSION}

No industry sector today is immune to labour exploitation. Thousands of people close to us, live and work in precarious conditions. Regardless of the nature of the business - sewing, construction, or tourism - we can be sure for at least this much: low pay, forced labour on the brink of survival, and unfair and non-transparent commercial and employers' practices do exist.

Exploitation and human trafficking are so widespread that they can be defeated only by a massive approach involving all stakeholders - governments, employers, trade unions, workers and consumers of end products and services. Especially end-consumers like all of us, we need to unite a voice in support of governments and local communities to insist on decent working conditions for all. Legislation in this area should be made transparent and protecting the rights of workers.

\section{ACKNOWLEDGEMENT}

This paper is a result of the author's work in frame of research project № NID NI-10/2018: "Money Laundering from Human trafficking" financed by University of National and World Economy, Sofia.

\section{REFERENCES}

[1] Krasteva, V., McDonnell, A., I. Tolgensbakk. (2019) Mobile young people: the subjective experiences of migration and return, In: Hvinden, B., O’Reilly, J., Schoyen, M. A., Hyggen, C. (Eds), Negotiating Early Job Insecurity: Scarring, Resilience and Well-being of European Youth, Edward Elgar Publishing, pp. 161-181.

[2] Outshoorn, J. (2015) The Trafficking Policy Debates. In: Dragiewicz, M. (Ed.), Global Human Trafficking: Critical Issues and Contexts, London: Routledge, 2015, pp. 7-22.

[3] United Nations Office on Drugs and Crime. (2008) Toolkit to Combat Trafficking in Person, New York: United Nations, available at: https://www.unodc.org/documents/middleeastandnorthafrica/global_report_on_trafficking_in_persons/07-89375_Ebook5B15D.pdf.

[4] The World Bank. (2018) Piecing Together the Poverty Puzzle, Washington: International Bank for Reconstruction and Development/The World Bank, available at: https://openknowledge.worldbank.org/bitstream/handle/10986/30418/9781464813306.pdf. 
[5] International Labour Organization. (2017) Global estimates of modern slavery: forced labour and forced marriage, Geneva: International Labour Organization and Walk Free Foundation, available at: https://www.ilo.org/wcmsp5/groups/public/@dgreports/@ dcomm/documents/publication/wcms 575479.pdf.

[6] UNICEF. (2016) The Sustainable Development Goals that Aim to End Human Trafficking, available at: https://www.unicefusa.org/stories/sustainable-development-goals-aim-end-human-trafficking/29864.

[7] Report from the Commission to the European Parliament and the Council. (2018) Second report on the progress made in the fight against trafficking in human beings as required under Article 20 of Directive 2011/36/EU on preventing and combating trafficking in human beings and protecting its victims, available at: http://www.europarl.europa.eu/doceo/ document/A-8-2016-0144_EN.html.

[8] Krasteva, V. (2019) Youth Employment and Precarious Work: The case of Bulgaria, Sofia: Academic publishing „Prof. Marin Drinov” (in Bulgarian).

[9] Bendit, R. (2006) Youth Sociology and Comparative Analysis in the European Union Member States, Papers, 79, pp. 49-76.

[10] Standing, G. (2011) The Precariat The New Dangerous Class, London: Bloomsbury Academic.

[11] Petrunov, G. (2014) Human Trafficking in Eastern Europe: The Case of Bulgaria. The Annals of the American Academy of Political and Social Science, 653(1), pp. 162-182. DOI: $10.1177 / 0002716214521556$.

[12] Sustainable development goals 2030, available at: https://sustainabledevelopment.un.org/ post2015/transformingourworld.

[13] Yordanova, G. (2016) Distance work-advantages and disadvantages through the prism of women. In: Economic Sociology 4.0, Sofia: UNWE, pp. 105-111, available at: http://www. unwe.bg/uploads/Department/Sociologia.ZA.PECHAT.pdf (in Bulgarian).

[14] Riebling, J. R., Stoilova, R., Hofäcker, D. (2016) Habits or Frames? - Explaining Patterns in the Division of Paid and Unpaid Work in Germany, Bulgaria, France and Hungary, In: Roosalu, T., Hofacker, D. (Eds.), Rethinking Gender, Work and Care in a New Europe Theorising Markets and Societies in the Post-Post socialist Era (pp. 215-230), Palgrave Macmillan.

[15] Lombardo, E., Agustin, L. R. (2011) Framing Gender Intersections in the EU. What Implications for the Quality of Intersectionality in Policies? Social Politics, 19(4), pp. 482-512.

[16] United Nations General Assembly. (2016) New York Declaration for Refugees and Migrants. Available at: http://www.unhcr.org/new-york-declaration-for-refugees-and-migrants.html.

[17] Stoilova, R., Krasteva, V., Yordanova, G. (2017) The role of employers on the labour market in Bulgaria. Sociological problems, Special Issue 49, pp. 36-59.

[18] Krasteva, V. (2017) Entering labour market in time of crisis: the vision of job-seekers. In: Economics \& Management: Globalization challenges, Belgrade, Serbia, available at: http://www.eraz.org.rs/archive-20152016.html. 